\title{
University Students' Attitudes Towards Online English Postgraduate Programs
}

\author{
Ranwa Khorsheed \\ Arab International University, Syria; \\ Syrian Virtual University, Syria \\ Suzan Deeb \\ Arab International University, Syria; \\ Syrian Virtual University, Syria \\ Rasha Al Dahhan \\ Arab International University, Syria; \\ Syrian Virtual University, Syria
}

\begin{abstract}
This paper aims to discuss students' attitudes towards enrolling in online English postgraduate programs at Virtual universities with a special reference to the Syrian Virtual University. It would therefore highlight the benefits that students get at these virtual universities as an alternative to traditional on campus education. Several points will be unwrapped such as virtual universities being an alternative under certain circumstances, and students' perception of the educational process in terms of fulfillment.
\end{abstract}

Index Terms - online programs, virtual universities, traditional education

\section{INTRODUCTION}

\section{Online Learning:}

Online education, with its new and dynamic approaches of delivering content, offers students an exciting experience to interact and share learning. Therefore, instructors and educational experts must 'use the technology and innovations available today to motivate, inspire and educate the students of the $21^{\text {st }}$ century" (Hope E. Kentor, chapter 2). Despite the many challenges and initial resistance, online language learning has gained respectability and is becoming commonplace. It is seen as being more flexible, more convenient and, in some circumstances, cost-effective. Even though distance learning is not a new way of teaching, distance learning as we know it today has come a long way from its beginnings, both in purpose and method. Its evolution and progression in the last 300 years developed in proportion with technology development and innovations. Distance learning can be traced back to the $18^{\text {th }}$ century being common in the late 1800s. The advancement of technology paved the way for a rapid growth in distancing learning in the 1990s. This article discusses the evolution of distance education beginning with the use of parcel post, to radio, then to television, and finally to present-day online education.

\section{Correspondence:}

This kind of education is defined as "a method of providing education for nonresident students, primarily adults, who receive lessons and exercises through the mail, or some other device, and, upon completion, return them for analysis, criticism, and grading" (Encyclopedia Britannica, 2012). The main purpose was to create educational opportunities for the under-represented and for those without access to a traditional educational institution (Jonasson, 2001). However, correspondence study was looked down on as inferior education. Many educators considered correspondence courses as simply business operations. Even though it was Caleb Phillips who first offered weekly shorthand lessons on March 20, 1728 , many argue that this cannot be formally recognized as distance education since there is no record of two-way communication (Verduin \& Clark, 1991).

In fact, it was Isaac Pitman who was known as the pioneer of distance education. He also began teaching shorthand by correspondence in 1840 in Bath, England, but with a different method from Phillip's. He mailed postcards to students and instructed them to transcribe passages from the Bible into shorthand and return them by post to be corrected (Verduin \& Clark, 1991). Later on, other societies and colleges followed suit until, by the 1870s, the Illinois Wesleyan College became the first academic institution to offer degree programs "in absentia" (Emmerson, 2004, p. 2) hence laying the foundation for correspondence education. In the 1870s, there was also the Chautauqua Movement, which introduced correspondence education for adults initially beginning as a training program for Sunday school teachers and expanded gradually, ultimately offering four-year programs and granting certificates of study. In 1892, William Harper Rainey offered college-level correspondence courses at the University of Chicago (Scott, 1999), having 3000 students in 350 courses and 125 instructors. 


\section{Distance education and the Radio:}

Distance education made a change in direction in 1894 with the invention of the radio. Shortly after that, in 1906 the University of Wisconsin-Extension was founded as a distance teaching unit. In 1919, the University of Wisconsin professors initiated the first federally licensed radio station dedicated to educational broadcasting (Engel, 1936) to be followed by others ending with 176 educational institutions by the end of the 1920s. This number declined sharply due to the regulatory issues surrounding the radio and the economic crisis at the beginning of the Great Depression in 1929. Institutions struggled to survive. Ultimately, in an effort to harness radio broadcasting as a teaching medium, on May 11 , 1930, the Rockefeller Foundation and the Carnegie Foundation organized and funded the National Advisory Council for Radio in Education (NACRE) (Buckland \& Dye, 1991; New York Public Library, n. d). That same year, the Institute for Education by Radio (IER), where radio was used extensively in the classroom, was founded.

In spite of the thrive of educational institutions in the $1920 \mathrm{~s}$, using the radio as a medium for education was more popular in Europe and Latin America than in the United States, where radio broadcasting organizations were among the pioneers of distance education Greville Rumble (1986).

\section{Television and education:}

Educational television (ETV) is defined as "a medium which disseminates programs devoted to information, instruction, cultural or public affairs, and entertainment" (Koenig \& Hill, 1967, p. xv). The pioneers of educational television were the University of Iowa, Iowa State University, Kansas State University, the University of Michigan, and American University (Koenig \& Hill, 1967). Yet, in spite of the evolvement of technology and use of video as a teaching medium, distance education via television faced many obstacles including a freeze issued by the Federal Communications Commission (FCC) in 1948 on granting new television licenses to the countless demand for license applications. It was not until 1952 that the FCC complied to the educators' requests and television channels were allocated exclusively for education. Even though the use of television in education continued to grow until the early 1970s, the use of television which featured instructor and student asynchronous interaction gradually diminished. This was due to the fact that distance education was poorly produced. By the mid to late 1970s, however, this changed. The British Broadcasting Company (BBC) began to set a standard for American television course developers to follow (Verduin \& Clark, 1991)

\section{The internet:}

Online education is defined as a form of distance education that uses computers and the Internet as the delivery mechanism, with at least $80 \%$ of the course content delivered online (Allen \& Seaman, 2008; Shelton \& Saltsman, 2005). There were three phases in the development of online learning: the pioneer phase (where few academics experimented with online learning and were advocated by only a few), the communities of practice phase (this method began to gather more and more supporters), and the standardization phase (the best practice was acknowledged by university managers, who invited applied their academic staff to apply it. Online educational programs emerged in 1989 , when the University of Phoenix began using CompuServe, one of the first consumer online services (The University of Phoenix, n. d.). It was also this same university that first offered online education programs through the Internet in 1991 when the World Wide Web came into existence. Many institutes, organizations and universities followed suit. In 1998, New York University Online and The California Virtual University, and Western Governors University were established. However, with the exception of University of Phoenix, many of the fledgling online educational programs that were begun by traditional learning institutions did not survive. Among the many factors accounting for the demise of these online institutions was the lack of understanding of online pedagogy and online learning styles and lack of institutional support.

In the developing world as well, many countries were all too eager to harness this advancement in technology and offer a new trend of education to their disadvantaged populations afflicted by poverty, illiteracy and disease. Following the well-known model of the British Open University, countries such as Pakistan, India, and China have merged modern methods of teaching with new technologies in order to provide low-cost instruction for basic literacy and job training. Later on, Turkey joined those countries, and after only 12 years had almost one million students making it the sixth largest distance education program in the world (Demiray \& Mclsaac, 1993).

\section{Distance education nowadays:}

John Sener (2012) argues, "education has been, is being, and will continue to be cyberized" (p. 157). He defines "cyberize" as "adapt[ing] to digital technology or culture" (p. 125). Today, with the advancements in communications technology and the connectivity of computers and the Internet, distance education has become an indispensable integrated aspect of education. The convenience and affordability of distance education has allowed the proliferation and assertation of many educational institutes of this form.

Nevertheless, in spite of all the advancement in technology and online pedagogic methods, online learning is not suitable for all subject material. Traditional classrooms and laboratories are indispensable when it comes to practical and real-world practice (Kearsley 2002).

\section{Online language learning}

As a language learning climate, online guidance is simply starting to appreciate a similar fame previously experienced inside different controls for quite a while (Goodfellow and Lamy, 2009; Lamy and Hampel, 2007; Meskill and Anthony, 2010). The term online language learning (OLL) can allude to various learning game plans: a Web- 
encouraged class, a mixed or mixture course, or a completely virtual or online course. These conveyance designs, alongside the blend of the mechanical apparatuses utilized in that, cover much of the time with the distinctions in terminology having more to do with the level of substance that is conveyed on the web (for an itemized characterization, see Kraemer, 2008). Completely online language courses may have understudies never meeting with one another in a vis-à-vis setting. To add to the disarray, the term distance learning has additionally been utilized to allude to a portion of these internet learning conditions just as to the blend of more customary strategies, for example, correspondence courses and video chatting, encouraging procedures since quite a while ago utilized in the U.S. instructive framework.

\section{Effectiveness of online programs}

Specialized correspondence empowers educators to eliminate existing limits and become "pioneers in the field of on the web schooling" (Davis, 2005, p. 17). Rohfeld and Hiemstra (1995) expressed that educators have "the duty of keeping conversations on target, contributing extraordinary information and experiences, weaving together different conversation strings and course segments, and keeping up bunch amicability" (p. 91). Today, online guidance has various benefits over customary face-to face guidance. As per Smith and Meyen (2003), "the benefits of utilizing on the web guidance as a choice in instructor planning, understudy learning, and school-home cooperation go a long ways past the undeniable ones of adaptability on schedule and place and 'simply in time' conveyance" (p.35). Online guidance has improved connection between teachers and understudies and, among understudies, offbeat correspondence, as a benefit of online guidance, makes correspondence and conversation more intuitive. It permits them to impart and get criticism rapidly, which makes learning significantly seriously fascinating and more cooperative. Dynes, Cooper, Trudel and Guglietti, (1998) expressed that associations are a viable factor of fruitful on the web guidance. Besides, online guidance is more open, consequently understudies can access current data and assets, email, announcement sheets, and data sets. They can likewise audit course materials, select substance design, and get new information also, abilities. Besides, online guidance, through innovation and correspondence, gives a chance to improve understudy freedom and knowledge, and is self-paced also. Viability of online course materials has effectively been set up (Hiltz and Turoff, 2002). Because of constant changes in innovation in the period of data frameworks furthermore, consistent insurgency in the realm of broadcast communications, instructive foundations need to alter their strategies and modernize their frameworks to keep up. Right now, instructive foundations in the United States are scrambling to create online guidance programs that will keep them in sync with the opposition (Jaffee, 1999). Truth be told, the percent of foundations receiving on the web guidance developed from $49 \%$ in 2003 to $56 \%$ in 2005 (The Sloan Consortium, 2006). Instructive organizations need to take a gander at their courses and continually overhaul the strategies they use to best instruct their understudies. Additionally, educators need to overhaul techniques for instructing from conventional structures to on the web structures to stay aware of consistent and progressed changes in innovation, with the goal that understudies have a superior opportunity to be serious. The demeanor of workforce is a key to the achievement or disappointment of any new advancement or change. Understanding personnel mentalities toward online guidance is a principal step that may give experiences into the practicality of execution of online guidance just as the end of boundaries. Rogers (1995) recognized the significance of demeanor. He expressed that, "Influence will prompt a resulting change in unmistakable conduct (reception or dismissal) reliable with the perspectives held" (p. 11). Examining personnel mentalities is imperative to decide the degree of workforce getting, acknowledgment, furthermore, preparation for online guidance. Moore and Thompson (1997) inferred that compelling on the web guidance is "estimated by the accomplishment of learning, by the perspectives of understudies and instructors, and by profit from speculation" (p.59).

The handiness of web based learning as an viable method of instructing and learning has not just gotten the consideration of language instructors and experts, however has additionally 'extended their perspectives on the best way to make understudy arranged also, open finished learning conditions', the two significant parts of the informative language educating. Informative methodology of language instructing which is considered as the best hypothetical model since mid 1970s requests common language learning systems furthermore, more open-finished sorts of exercises, for example, pretends, data hole exercises, and reproductions in a informative circumstance, to comprehend the likely open capacities and social implications of the phonetic structures. Notwithstanding, research shows that the open methodology seems to have welcomed advancement more fair and square of hypothesis than fair and square of genuine homeroom rehearses. Albeit testing, it is important to defeat the inadequacies of the customary language instructing and learning techniques by coordinating suitable advancements and instructional methodologies in the second or unknown dialect training field. Consequently, most instructors and understudies appear to feel that there is a need to utilize ICT, especially PCs, CD-ROM interactive media and the Internet in ESL/EFL. This is presumably on the grounds that they feel that these materials are adaptable, intriguing, and engaging.

\section{Online language learning tools}

There are a few instruments accessible to the online language students. The Yale Center for Language Study has extensively arranged these instruments into sound account and altering (Vocaroo), photograph altering (Pixir), media projects (CLEAR's rich Internet applications), collective working what's more, composing (GoogleDocs), introduction (prezi), videoconferencing (Skype), word references and jargon learning (wordreference), video-creation and altering (Amara), and site and e-portfolios (Weebly). Another analyst Jeong-Bae Son has made elite of online instruments that are presently accessible and unreservedly available on the Internet. On the premise of their primary capacities and highlights, the on the web devices have been gathered into twelve classes (learning/content administration frameworks; 
correspondence; live furthermore, virtual universes; informal communication and bookmarking; web journals and wikis; introduction; asset sharing; Website creation; Web practice creation; web crawlers; word references and concordancers; and utilities ,informative abilities and improving oral capability. This can be accomplished through online guidance (WBI) program, which gives openness to practical language learning conditions and subsequently makes the language learning more intelligent and exuberant. A language learning program dependent on WBI gives practice in the four language abilities, perusing, composing, tuning in and talking.

\section{Principles of online language learning}

The audit of writing proposes that an on the web learning climate ought to be founded on the accompanying standards which have been gotten from the arranged learning hypothesis: (a) arrangement of credible exercises inside settings, (b) benchmarking specialists' reasoning and execution, (c) bountiful data and different focuses of view, (d) opportunity for pragmatic reflection, (e) agreeable development of information, (f) explanation of thinking, and (g) training. A few analysts have revealed that WBI alongside PC interceded correspondence (CMC), furnishes students with rich and valid language learning climate, and 'an encounter of expanding inspiration, shared learning and social collaboration which are important to the students in the language homeroom'. Strangely, some exploration has discovered a more noteworthy effect of CMC on understudy's composition capability than a vis-à-vis correspondence during a semester. A few specialists, be that as it may, have additionally raised questions about the viability of these internet learning frameworks and have posed inquiries about the significance of web based learning at all levels. As indicated by them, not every person engaged with instructing and learning acknowledges the cases of the benefits, yet rather holds an incredulous view. Such perspectives result either because of absence of familiarity with the points and destinations of WBI, or absence of compelling frameworks vital for its usage. Likewise, the quantity of research completed on the adequacy of online language learning is very irrelevant. It merits referencing here that the writing survey didn't uncover any exploration about the adequacy of online guidance or online language learning corresponding to students' in general language capability including the four language abilities like perusing, composing, tuning in, and talking at any level. Indeed, even in different pieces of the world, the accessible contemplates are restricted to the powerful securing of composing abilities or perusing abilities in second or unknown dialect learning. There is almost no examination done in the region of tuning in and oral capability acquired through on the web learning frameworks. Like some previous examinations, Cho and Lee's research concentrates additionally demonstrated that composing capacity grown more in WBI classes than customary classes. In another examination by Kim, nonetheless, the finding was unique. She detailed that in an online English perusing course, 'the real yield execution level accomplished through CMC connection was not exactly proportionate with past assumptions, particularly not in wording of shared learning'. Kim [16] completed one more trial to assess the impacts of CMC on understudies' oral capability utilizing a voicecorrespondence CMC program. She played out this examination with three distinctive instructional settings, a FFC-just setting, a CMC-just setting, and a setting where FFC was followed by CMC, and found no huge setting impact for the proportions of oral capability.

\section{METHODOLOGY}

\section{Students' views regarding online English programs}

A questionnaire was devised to elicit responses from students at the Syrian Virtual University. A randomly selected group participated in the questionnaire.

The questionnaire consists of five parts. The first part collects demographic information about the participants, the second elicits students' reasons for enrolling at the Syrian Virtual University, and the third explores the students' attitudes towards online education in addition to their views on the SVU programmes. The fourth part is concerned with students' perspectives about pursuing post-graduate studies via online English programmes at British universities. The last part presents the challenges students anticipate to face in online education. In addition, it presents their suggestions for possible solutions that might help Syrian students to pursue their postgraduate studies in Britain.

\section{RESUlTS AND DISCUSSION}

The participants were $52.5 \%$ females and $47.3 \%$ males. Their ages ranged from 20 to 51 , the majority being 25 . They were enrolled in different programmes including Computer Engineering, Information Technology, Communications Technology, Business Administration, Economics, etc.

Even though most of the enrolled students were unemployed, the others worked in different fields such as cellular network technicians, teachers, accountants, graphic designers, HR and web designers, etc.

When asked about the reason(s) they chose to study at SVU, 78.95\% responded that it allows them to study and work at the same time, while 50\% said that it was more affordable than any other private university. $21.1 \%$ strongly agreed and 52.6\% agreed that they chose SVU because it provided a safe learning environment and 57.9\% agreed that SVU offers the opportunity to pursue post graduate studies. $42.1 \%$ agreed that SVU offers the educational programs needed for the job market after graduation. $15.8 \%$ strongly agreed and $42.1 \%$ agreed that the SVU certificate is recognized by other universities and companies abroad. Other reasons shared by lesser percentages were family circumstances and reasons other than the ones stated. 
When asked about studying online at a British university, $50 \%$ strongly agreed and $31.6 \%$ agreed that they would like to pursue their post-graduate studies at a British university. Hence, $65.8 \%$ strongly agreed and $34.2 \%$ agreed that there should be joint programmes between SVU and British universities. Moreover, 34.2\% strongly agreed and 36.8\% agreed that in relation to British universities, distance learning is more convenient than traditional learning.

Enrolling in online programs would help Syrian students on several aspects. 57.9\% strongly agreed and $28.9 \%$ agreed that distance learning at a British university saves students in Syria the trouble of travelling, residency, visas and living expenses. $65.8 \%$ strongly agreed and $31.6 \%$ agreed that obtaining a visa to Britain is a main obstacle in pursuing their studies at a traditional British university. 50\% strongly agreed and $42.1 \%$ agreed that the unavailability of language exam centers in Syria or difficulty accessing these centers outside Syria is another major obstacle in studying at a traditional British university. Consequently, $47.4 \%$ strongly agreed and $44.7 \%$ agreed that distance learning at a British university is recognized and accredited and would solve the aforementioned obstacles.

As for the courses the students prefer to study. 5.3\% would like to study crisis management via distance learning at a British university. Lesser percentages include other specializations such as MBA and Artificial Intelligence.

When asked about the difficulties students expect to face when enrolling in a distance program at a British university, most were concerned about their lack of English language proficiency and the slow Internet connection in Syria. Other responses included high tuition fees and unavailability of language exam centers in Syria.

When asked about their suggestions for making distance learning at British universities available, students proposed making the programs affordable and providing secure channels through which students can pay the tuition fees. This, according to the participants in the questionnaire, includes lifting sanctions on Syria, which will allow the Ministry of Higher Education in Syria to collaborate with British university and, consequently offer joint scholarships. Participants also suggested opening centers and branches for British universities in Syria, or at least reopening the British Council in Damascus so that students can have access to the English language and culture. If taken, students think that this step would solve lots of problems related to having English language proficiency tests and provide students with an official institute that represents the British universities in Syria.

\section{CONCLUDING REMARKS}

Being Syrian scholars, who live in Syria and who aspire to further pursue postgraduate studies in English at British universities, it was our aim and mission to deliver the message embedded in this paper on behalf of all Syrian students. Many dreams have been crushed deferred or put to sleep but; nevertheless, the Syrian youths have never stopped dreaming and will keep looking for a new hope and opportunities.

\section{REFERENCES}

[1] Allen, I. E., \& Seaman, J. (2008). Sizing the opportunity: The quality and extent of online education in the United States. Retrieved 12/4/2020 from http://sloanconsortium.org/publications/survey/sizing_the_opportunity2003.

[2] Association of Commonwealth Universities. (2019). The Road to 2013. Building a better world through higher education. Strategy 2019-2015 (online). Available at https://www.acu.ac.uk/about-us/acu-strategy-the-roadto-2030 (Accessed March 2019).

[3] Becker, R., R. Kolster (2012). International student recruitment: policies and development in selected countries. Netherlands organization in higher education.

[4] Bhandari, R., \& Blumethal, P.( 2009). Global student mobility in International Institute for Education ed Higher education on the move IIE, New York 1-15.

[5] Bilecen,B., \& Van Mol,C. (2017). Introduction: international academic mobility and inequalities, Journal of Ethnic and Migration Studies, 43:8, 1241-1255, DOI:10.1080/1369183X.2017.1300225.

[6] Bourdieu, P., \& Passeron, J. (1997). Reproduction in education, society and culture Sage, London

[7] Brooks, R., \& Waters, J. (2010). Social networks and educational mobility Globalisation, Societies and Education $10143-57$

[8] Brown, P. (1995). Cultural capital and social exclusion Work, Employment and Society $929-51$.

[9] Buckland, M., \& Dye, C. M. (1991, October). The development of electronic distance education delivery systems in the United States. Recurring and emerging themes in history and philosophy of education. Paper presented at the Annual Conference of the Midwestern Educational Research Association, Chicago, IL. Retrieved from ERIC Clearinghouse.

[10] Byram, M., \& Dervin,L. (2008). eds Students, staff and academic mobility in higher education Cambridge Scholars Publishers, Newcastle.

[11] Daher, S. (2014). The predictive validity of IELTS amongst a group of MA Syrian students. Tishreen University Journal for Research and Scientific Studies- Arts and Humanities Series, 36(1), 405-418. Retrieved 2/4/2020 from http://95.159.58.55/index.php/humlitr/article/view/687.

[12] Demiray, U., \& McIsaac, M. S. (1993). Ten years of distance education in Turkey. In B. Scriven, R. Lundin, \& Y. Ryan (Eds.), Distance education for the twenty-first century (pp. 403-406). Oslo, Norway: International Council for Distance Education.

[13] De Wit, H. (2008). Changing dynamics in international student circulation in de Wit H, Agrawal P, Said M E, Sehoole M T and Sirozi M eds The dynamics of international student circulation in a global context. Sense Publishers, Rotterdam 15-45

[14] Edwards, R., \& Usher, R. (2000). Globalisation and pedagogy Routledge, London

[15] Emmerson, A. M. (2004). A history of the changes in practices of distance education in the Unites States from 1852-2003. Ed. D. Dissertation, Dowling College, New York, NY. Dissertations \& Theses. (Publication No. AAT 3157941.) Retrieved 1/4/2020 from http://0search.proquest.com.bianca.penlib.du.edu/docview/305342174?pqorigsite=summon. 
[16] Findlay, A. M., D. McCollum, \& H. Packwood. (2017). "Marketization, Marketing and the Production of International Student Migration." International Migration 55 (3): 139-155.

[17] Ginther, A., \& McIntosh, K. (2018). Language Testing and Assessment. DOI:10.1057/978-1-137-59900-1_39.

[18] Gulson, K., \& Symes, C. (2007). Knowing one's place in Gulson K and Symes C eds Spatial theories of education 1-16. Routledge, London.

[19] Gunn-Lewis, J. (n.d). English Entry Levels and Academic Success. UNITEC Institute of Technology.

[20] Gu“" ru“z, K. (2008). Higher education and international student mobility in the global knowledge economy State University of New York Press, Albany NY

[21] HEFCE. (2004). International student mobility Issues Paper 2004 / 30 HEFCE, London Higher Education International Unit 2010 Motivating outward mobility International Focus 501.

[22] Herrera,L. (2006). "Higher Education in the Arab World," in International Handbook of Higher Education, ed. James Forest and Philip Altbach (Dordrecht, The Netherlands: Springer, pp. 409-21.

[23] Higher Education Statistic Agency (HESA). (2016). Introduction - Students 2015/16. (Online) Available at: https://www.hesa.ac.uk/data-and-analysis/publications/students-2015-16/introduction (accessed February 2018).

[24] Jonasson, J. (2001). On-line distance education a feasible choice in teacher education in Iceland? Unpublished master's thesis. University Strathclyde, Glasgow, U. K. Retrieved 3/3/2020 from https://notendur.hi.is/jonjonas/skrif/mphil/thesis.pdf.

[25] Kapiszewski, A. (2006). "Arab versus Asian Workers in the GCC Countries," Working Paper (United Nations, Population Division).

[26] King, R \& Ruiz-Gelices, E. (2003). International student migration and the European 'year abroad' International Journal of Population Geography $9229-52$

[27] Koenig, A. E., \& Hill, R. B. (1967). The farther vision: Educational television today. Madison, WI: The University of Wisconsin Press

[28] Krieger,Z. (2007). "Dubai, Aiming to Be an Academic Hub," The Chronicle of Higher Education 54, no. 8 (12-20).

[29] Kuptsch, C. (2006). Students and talent flow - the case of Europe in Kuptsch C and Pang E eds Competing for global talent ILO, Geneva 33-62.

[30] Lefebvre, H. (1991). The production of space. Blackwell, Oxford.

[31] Lomer,S. (2018). UK policy discourses and international student mobility: the deterrence and subjectification of international students, Globalisation, Societies and Education,16:3, 308-324, DOI: 10.1080/14767724.2017.1414584

[32] Marginson, S \& Van der Wande, M. (2007). 'Globalisation and higher education' Education Working Group Paper 8 OECD, Paris

[33] Marginson, S. (2008). "Global Field and Global Imagining: Bourdieu and Worldwide Higher Education." British Journal of Sociology of Education 29 (3): 303-315.

[34] Mazawi, A.E. (2000). Aspects of Higher Education in the Arab States," International Higher Education 18. Retrieved 2/5/2020 from http://www.bc.edu/ bcorg/avp/soe/cihe/newsletter/News 18/text9.html.

[35] Mazawi,A.E. (2005). "The Academic Profession in a Rentier State: The Professoriate in Saudi Arabia," Minerva 43 (2005): pp. 221-44.

[36] Morsi,M. (1990). Education in the Arab Gulf States (Doha, Qatar: University of Qatar, Educational Research Center).

[37] Murphy-Lejeune, E. (2002). Student mobility and narrative in Europe Routledge, London

[38] Nada, C. I., \& Araújo, H. C. (2018). 'When you welcome students without borders, you need a mentality without borders' internationalisation of higher education: evidence from Portugal. Studies in Higher Education, 1-14. al science students in the UK. Mobilities, 12(3), 425-444.

[39] Noble, J \& Davies, P. (2009). Cultural capital as an explanation of variation in participation in higher education. British Journal of Sociology of Education 30 591-605.

[40] Ong, A. (1999). Flexible citizenship Duke UP, Durham NC

[41] Papatsiba, V. (2006). Making higher education more European through student mobility? Comparative Education $4293-111$

[42] Ploner, J. (2017). Resilience, moorings and international student mobilities - exploring biographical narratives of social science students in the UK. Mobilities, 12(3), 425-444. https://doi.org/10.1080/17450101.2015.1087761.

[43] Roy, W. (2016). The PTE Academic and outer circle students: assessing proficiency in English, ownership of English, and academic performance at UK universities. PhD thesis, University of Warwick.

[44] Rosenfield, A. (2018). In their own words: Can transnational students decolonize the English Canadian university? Sociology. London.

[45] Rumble, G. (1986). The planning and management of distance education. London, UK: Croom Helm

[46] Scott, J. C. (1999). The Chatauqua movement: Revolution in popular higher education. The Journal of Higher Education, 70(4), $389-412$

[47] Sener, J. (2012). The seven futures of American education: Improving learning and teaching in a screen captured world. North Charleston, SC: CreateSpace

[48] Shelton, K., \& Saltsman, G. (2005). An administrator's guide to online education. Greenwich, CT: Information Age Publishing.

[49] Sidhu, R. K. 2006. Universities and Globalization: To Market, to Market. London: Routledge.

[50] Tapper, T. \& Palfreyman, D .eds. (2004). Understanding mass education Routledge, London

[51] Kearsley, G. (2002). Is online learning for everybody? Educational Technology,42(1):41-4

[52] Khodashenas, T, M. (2011). Fairness of IELTS Test Scores in University Admission. Higher Education Studies 1:10.5539/hes.v1n2p107-113.

[53] Teichler, U. (2004). The changing debate on internationalization of higher education. Higher Education 48 2-26

[54] Taylor, G., \& Ali, N. (2017). Learning and living overseas: exploring factors that influence meaningful learning and assimilation: how international students adjust to studying in the UK from a socio-cultural perspective. Education Sciences, $7(1), 1-25$. 
[55] UK Council for International Student Affairs (UKCISA). (2018). International student statistics: UK higher education. Retrieved 1/5/2020. Available at: https://www.ukcisa.org.uk/Research\%2D\%2DPolicy/Statistics/Internationalstudentstatistics-UK-higher-education.

[56] UNESCO. (2015). SDG4-Education 2030, Incheon Declaration (ID) and Framework for Action. For the Implementation of Sustainable Development Goal 4, Ensure Inclusive and Equitable Quality Education and Promote Lifelong Learning Opportunities for All, ED-2016/WS/28.

[57] Varghese, N. (2008). Globalization of higher education and cross border student mobility International Institute for Education Planning, Paris

[58] Verduin, J. R., \& Clark, T. A. (1991). Distance education. Oxford, UK: Jossey-Bass Publishers

[59] Waters, J. (2006). Geographies of cultural capital: education, international migration and family strategies between Hong Kong and Canada. Transactions of the Institute of British Geographers 31 179-92. Sage Journal.

[60] Williams, A., \& Balaz, M. (2009). International migration and knowledge Routledge, London

[61] Woodrow, L. (2006a). Academic success of international postgraduate education students and the role of English proficiency. University of Sydney Papers in TESOL 1: 51-70.

[62] Wu, X., \& Wu, J. (2020). Criteria evaluation and selection in non-native language MBA students admission based on machine learning methods. J. Ambient Intell. Humaniz. Comput., 11, 3521-3533.

[63] Yang,R. (2003). Globalization and higher education International Review of Higher Education $49269-91$.

Ranwa Khorsheed was born in Damascus. She received her MA in Linguistics in 2014. She is currently a lecturer at the Arab international university and the Syrian virtual university. She is interested in cognitive and corpus linguistics. She is a sworn Translator. She has published several papers on language teaching and co-authored a book on academic writing and research. She has recently got five certificates (Sustainability in higher education, digital skills, women empowerment, soft skills, and gender equality), from UNED- sponsored by Erasmus.

Susan Deeb is an English Language Instructor at the Arab International University and Syrian Virtual University. She received her BA and MA from Damascus University's Department of English. Deeb has taught English Language at Damascus University and Higher Language Institute for seven years. She has published in Coldnoon, International Journal of Travel Writing \& Travelling Cultures as her research interest is focused on the integration of gender and ethnicity as roots and routes in African American women's road narratives.

Rasha Al Dahhan is a graduate of the English Department/ Damascus university and a holder of a Master degree in interpreting and translation. She worked for several Syrian Universities including the Syrian virtual university and the Arab international university. She is interested in online education She has recently got five certificates (Sustainability in higher education, digital skills, women empowerment, soft skills, and gender equality), from UNED- sponsored by Erasmus. 